Sebastian Wasiuta

Uniwersytet Marii Curie-Skłodowskiej, Lublin

sebastian.wasiuta@umcs.pl

\title{
PRZYSŁOWIE JAKO JEDNOSTKA JĘZYKA (W PERSPEKTYWIE TEKSTOLOGII INTEGRALNEJ)
}

Słowa kluczowe: definicja tekstu, tekst prototypowy, tekst minimalny, tekstem, tekstologia, przysłowie, jednostki języka

Keywords: definition of text, prototypical text, minimal text, texteme, textology, text linguistics, proverb, linguistic units

\section{Wstęp}

W artykule O podstawach ogólnej charakterystyki przysłów Andrzej Bogusławski stwierdził, że

[...] właściwą ojczyzną przysłowioznawstwa może się okazać kształtująca się coraz wyraźniej dyscyplina, którą można by nazwać nauką o tekście czy też tekstologią (Bogusławski 1976: 145).

Niedawno na rynku wydawniczym pojawiła się koncepcja tekstologii przedstawiona przez Jerzego Bartmińskiego i Stanisławę Niebrzegowską-Bartmińską (2009)

1 Autorzy posługują się nazwą tekstologia w znaczeniu szerszym niż utrwalone w filologii. Tradycyjnie, od publikacji pracy Borysa Tomaszewskiego Pisatel' i kniga. Očerk tekstologii (1928), tekstologią nazywano „zespół dochodzeń filologicznych mających na celu ustalenie tekstu zgodnego $\mathrm{z}$ intencją pisarza i prześledzenie na podstawie istniejącej dokumentacji, jak przebiegały poszczególne stadia jego kształtowania się" (Górski 2011: 6; zob. też Loth 2006: 17-18). W tej tradycji, którą podtrzymują podręczniki Zbigniewa Golińskiego (1969), Konrada Górskiego (2011) i Romana Lotha (2006), zawierające ów termin w tytułach, tekstologia jest synonimem edytorstwa; nie jest 
Korzystając z niektórych wyłożonych $\mathrm{w}$ niej propozycji, chciałbym przedstawić możliwości traktowania przysłowia jako jednostki języka².

\section{Definicja tekstu}

Tekst, jak zauważa S. Niebrzegowska-Bartmińska (2007), traktowany jest przez językoznawców dwojako. $Z$ jednej strony jest on postrzegany jako „konstrukcja składająca się z jednostek językowych, ciąg zdań, któremu przysługuje spójność linearna” (tak u Mayenowej (1974); Bogusławskiego (1983); Dobrzyńskiej (1991)), z drugiej zaś jako jednostka języka i komunikacji (tak np. Duszak (1998); Bartmiński (1998); Niebrzegowska-Bartmińska (2007)). Ten drugi sposób upowszechnia się w badaniach językoznawczych - do jego zwolenników, poza wymienionymi badaczami, należą m.in. także Barbara Boniecka (1999), Bożena Witosz (1998), Urszula Żydek-Bednarczuk (2005). Stanowisko to ma również za sobą autorytet Michaiła Bachtina, który w swej koncepcji gatunków mowy traktował wypowiedź (scil. tekst) jako ,jednostkę językowego porozumiewania się" (Bachtin 1986: 357), choć nie jednostkę języka (opis tego ostatniego Bachtin kończył bowiem na słowie i zdaniu).

Definicję tekstu właściwą dla tekstologii integralnej J. Bartmiński przedstawił w artykule Tekst jako przedmiot tekstologii lingwistycznej (Bartmiński 1998). W ujęciu badacza

[...] tekst jest to ponadzdaniowa jednostka językowa, makroznak, mający nacechowanie gatunkowe i stylowe (kwalifikator tekstu), poddający się całościowej interpretacji semantycznej i komunikatywnej, wykazujący integralność strukturalną oraz spójność semantyczną i podlegający wewnętrznemu podziałowi semantycznemu, a w przypadku tekstów dłuższych - także logicznemu i kompozycyjnemu (Bartmiński 1998: 17).

to jednak ujęcie wyłączne, por. tytuły książek Jana Trzynadlowskiego (1976) i Łukasza Garbala (2011). Najwcześniej z dziedzin humanistycznych tekstami zajmowały się biblistyka i nauka o literaturze. Obecnie dąży się do przełamania niezwykle ostrego kiedyś oddziału analiz literaturoznawczych od językoznawczych i w rezultacie do zintegrowania badań tekstów w ramach jednej dyscypliny, określanej jako tekstologia integralna (zob. Bartmiński, Niebrzegowska-Bartmińska 2009: 12). Według S. Niebrzegowskiej-Bartmińskiej współczesna integralna tekstologia „w teorii i w praktyce łączy świat języka, literatury, komunikacji i kultury. Centralną pozycję w tym świecie zajmuje człowiek, który jest rzeczywistym przedmiotem badań językoznawczych, literaturoznawczych, komunikacyjnych i kulturowych" (Niebrzegowska-Bartmińska 2015: 8).

2 Rezygnuję $\mathrm{w}$ tym miejscu $\mathrm{z}$ omówienia odmiennego pojmowania jednostki języka przez różnych językoznawców. Zawiera je podrozdział Trudności (?) tekstologii integralnej mojej rozprawy doktorskiej (Wasiuta, w przygotowaniu). Wspomnę jedynie, że zwolennicy tradycyjnie ukierunkowanego językoznawstwa nie akceptują genus proximum definicji tekstu, o której mowa poniżej, sformułowanej przez Bartmińskiego. 
Definicja ta została - w nieznacznie tylko zmodyfikowanej formie - powtórzona w podręczniku Tekstologia (Bartmiński, Niebrzegowska-Bartmińska 2009: 36). Tekst został tym samym wpisany w zespół podstawowych pojęć i terminów lingwistycznych (por. ibid.: 37):

\begin{tabular}{|lll|}
\hline Poziom opisu języka & Użycie & System \\
\hline tekstowy & tekst & tekstem \\
\hline składniowy & zdanie $^{3}$ & model zdaniowy \\
\hline leksykalny & wyraz tekstowy & leksem \\
\hline morfologiczny & morf & morfem \\
\hline fonologiczny & głoska & fonem \\
\hline
\end{tabular}

Powyższe zestawienie odbiega od ujęć tradycyjnych w trzech punktach. Po pierwsze, na mocy przyjętej definicji tekstu do systemowo zorganizowanych poziomów języka zalicza się poziom tekstowy, wraz z jego jednostkami. Po drugie, odwraca się hierarchię poziomów i - za Wilhelmem von Humboldtem ${ }^{4}$ - najwyżej stawia właśnie ów poziom tekstowy. Spośród wszystkich jednostek języka tekst jest najbardziej oczywisty, najbliższy potocznemu doświadczeniu posługiwania się językiem. W hierarchii powyższej schodzi się ku bardziej szczegółowym - a zarazem coraz bardziej abstrakcyjnym - warstwom języka, zgodnie z propozycją (alternatywną) Noama Chomskiego (1957: 59). Po trzecie, użycie stawia się przed systemem, wychodząc z założenia, że typowy użytkownik przede wszystkim obcuje z konkretnymi jednostkami i nimi się posługuje („działa), natomiast wiedza o systemie i znajomość jego jednostek jest wtórna do praktycznego posługiwania się językiem5. Rozumowanie to jest zgodne ze stwierdzeniem Ferdinanda de Saussure’a: „Wszystko

3 U Grzegorczykowej (1999) - schemat składniowy vs wypowiedzenie; u Furdala (1990) - środki składniowe vs zdanie.

4 Zob. w tej sprawie wstęp tłumaczki do Rozmaitości języków a rozwoju umysłowego ludzkości, pośmiertnie wydanej rozprawy Humboldta: „Umieszczenie [przez Humboldta - S.W.] wypowiadania w centrum uwagi językoznawstwa powoduje $z$ jednej strony konieczność uwzględnienia tekstu, z drugiej zaś systemu językowego. [...] mowa [w koncepcji Humboldta - S.W.] ma jednak zdecydowany priorytet logiczny”. Na potwierdzenie tych słów przytacza ona fragmenty z innych pism Humboldta: „Człowiek pierwotnie myśli całą myśl jako jedność i tak też ją wypowiada [...]. Jeśli chcemy zbadać naturalną kolej rzeczy, nie można pomyśleć gramatyki jako składania mowy z wyrazów, lecz tylko jako rozkładanie mowy na wyrazy. Mowa, a nie wyraz jest w naturze tym, co pomyślane najpierw i pierwotnie”, a w innym miejscu: „Gramatyka, nie tylko jako nauka, lecz prawdziwie przez czyn, jako budowa gramatyczna, powstaje przez rozkładanie mowy na jej elementy [...]" (Humboldt 1836/2001: 21).

5 Te założenia stały się podstawą sformułowanej przez J. Bartmińskiego koncepcji nauczania przedmiotu „współczesny język polski” w Instytucie Filologii Polskiej UMCS, opartej właśnie na układzie treści „od góry do dołu” (Bartmiński 2004: 16). 
to istnieje w języku, lecz jako byty abstrakcyjne; badanie ich jest trudne, ponieważ nie możemy wiedzieć z całą pewnością, czy świadomość mówiących sięga zawsze równie daleko, jak analiza gramatyków" (de Saussure 1916/2002: 165).

Badacze tekstolodzy przyjmują różne kryteria tekstowości. Najczęściej przywołuje się listę siedmiu cech, sformułowaną we Wstępie do lingwistyki tekstu przez Roberta-Alaine’a de Beaugrande'a i Wolfganga Ulricha Dresslera (1990: 29-30). Twierdzą oni, że tekst jest: (1) spójny powierzchniowo i (2) pojęciowo, (3) ma jakąś intencję, (4) jest akceptowalny („akceptabilny”) - odbiorca nastawia się na odbiór tekstu mającego znaczenie, (5) niesie nową informację („informatywność”), (6) wiąże się z sytuacją („sytuacyjność”) oraz (7) ma związek z innymi tekstami („intertekstowość”).

Ta lista cech tekstu prototypowego została poddana krytyce, weryfikacji i poszerzeniu w Tekstologii (Bartmiński, Niebrzegowska-Bartmińska 2009). Wyróżnioną pozycję zyskała tam podmiotowość, której u de Beaugrande’a i Dresslera nie było (choć pojęcie podmiotu jest implikowane przez intencjonalność). Do relewantnych cech tekstu włączono również nacechowanie gatunkowe i stylowe, niewymieniane jako kryterium tekstowości przez Beaugrande’a i Dresslera. Względna zgodność dotyczy zaadresowania tekstu, spójności strukturalnej i semantycznej oraz podatności na przetwarzanie, które pojawiły się u de Beaugrande’a i Dresslera pod nieco innymi nazwami. Pełna zgoda między obu ujęciami istnieje co do cech intencjonalności tekstu, jego informatywności i sytuacyjności. De Beaugrande i Dressler występowali z pozycji strukturalistycznych, tymczasem ujęcie Bartmińskich ma podstawy antropologiczne, stąd zaakcentowanie roli podmiotu mówiącego (homo loquens), i kognitywistyczne, ponieważ wyprowadza się charakterystykę tekstu $\mathrm{z}$ danych obrazujących, jak pojęcie tekstu konceptualizują przeciętni użytkownicy polszczyzny.

Do cech prototypowych tekstu autorzy podręcznika do tekstologii zaliczają: intencjonalność i podmiotowość, nacechowanie stylowe i gatunkowe, linearność, integralność strukturalną, spójność treściową oraz informatywność (Bartmiński, Niebrzegowska-Bartmińska 2009: 50). Porównanie obu list kryteriów tekstowości wygląda następująco (por. ibid.: 48-49):

\begin{tabular}{|ll}
\hline Beaugrande, Dressler (1990) & Bartmiński, Niebrzegowska-Bartmińska (2009) \\
\hline- & podmiotowość \\
\hline akceptabilność & zaadresowanie \\
\hline intencjonalność & intencjonalność \\
\hline- & nacechowanie stylowe i gatunkowe \\
\hline- & linearność \\
\hline spójność powierzchniowa & integralność strukturalna \\
\hline spójność semantyczna (koherencja) & spójność treściowa (logiczna i semantyczna) \\
\hline
\end{tabular}


Beaugrande, Dressler (1990)

informatywność

sytuacyjność

intertekstowość
Bartmiński, Niebrzegowska-Bartmińska (2009)

informatywność

sytuacyjność

podatność na przetwarzanie

\section{Czy przysłowie jest tekstem?}

Przy tak zarysowanym tle należy powrócić do definicji tekstu oraz kryteriów tekstowości wymienionych przez Bartmińskich w Tekstologii, aby sprawdzić, w jakim stopniu owe kryteria można odnieść do przysłów.

Przyjrzyjmy się przykładom zaczerpniętym z Narodowego Korpusu Języka Polskiego, w których fragmentami są przysłowia (zaznaczam je przez wytłuszczenie), rozpoznawane intuicyjnie jako pewne - powiedzmy na razie ogólnie - „całostki”. Jaki jest ich status językowy w świetle podanych kryteriów tekstowości?

(1) Władze centralne i wojewódzkie SLD nas lekceważą, więc jak Kuba Bogu, tak Bóg Kubie - stwierdził Jan Osuchowski, prezydent Raciborza. Od maja przestał płacić partyjne składki na Sojusz Lewicy Demokratycznej, do którego należał (J. Bombor, Nie zapłacę!, „Trybuna Śląska”, 3 XII 2004).

Przysłowie podkreślone w przykładzie (1) jest eksplicytnie przypisane określonemu nadawcy („stwierdził Jan Osuchowski, prezydent Raciborza”), ma zatem cechę podmiotowości; zawiera pewną intencję, przywołuje sytuację usprawiedliwiającą postępowanie nadawcy („lekceważenie nas” przez wyższe instancje SLD); można je wyraźnie wyodrębnić w wypowiedzi, ma ostry kontur (integralność) i semantyczną spójność. Jest informacyjne, orzeka o rzeczywistości oraz zostało zaadaptowane do kontekstu wypowiedzi, w której się pojawia (wobec danego sposobu traktowania lokalni działacze SLD mają prawo odpowiedzieć lekceważeniem na lekceważenie).

Integralność przysłów jest najwyraźniej widoczna, kiedy są one powtarzane w ustabilizowanej formie. W dłuższych tekstach paremie są przez autorów wyraźnie wyodrębniane (przytaczane, cytowane) i opatrywane kwalifikatorami gatunkowymi, np.:

(2) Osobiście bardzo lubię przysłowia. Można z niektórych budować całe ciągi pedagogiczne, służące umoralnianiu młodzieży. Na przykład - na pochyłe drzewo wszystkie kozy skaczą, plus gdyby kózka nie skakała, toby nóżki nie złamała. I już wiadomo, że skakać na pochyłe drzewo nie należy, bo można mieć przetrąconą nóżkę. Są też przysłowia sprzeczne wzajemnie - szlachcic 
na zagrodzie równy wojewodzie. Ale: co wolno wojewodzie, to nie tobie, smrodzie (Maciej Radwan Rybiński, Przysłowiowe przysłowia, bynajmniej, „Dziennik Polski”, 1 IV 2005).

Autor wypowiedzi (2) określone zdania wyróżnia jako cytaty (przytaczane z obiegu potocznego) za pomocą operatora metatekstowego na przykład i dwukrotnie użytego wyrażenia gatunkowego przysłowie.

W przykładzie (3) takim wyrażeniem quasi-gatunkowym jest określenie zasada, będące tu synonimem przysłowia, a dodatkowo informujące, że paremie komunikują pewne normy przyjęte w danej wspólnocie komunikacyjno-kulturowej.

(3) Dokonując prostej, przedstawionej powyżej kalkulacji, dochodzą do wniosku, że dali zarobić towarzystwu na czysto wszystkie wpłacone składki klienta, nie dostając z tego ani grosza. Po prostu pracowali za darmo! W myśl zasady „jak Kuba Bogu, tak Bóg Kubie”, wobec postępującej nieuczciwie firmy sami zaczynają działać nieuczciwie. Pieniędzy zwracać nie chcą. Oczywiście, w świetle prawa są osobami, które łamią przepisy (Hanna D.M. Kustosz, Wielki strach na wróble, „Gazeta Ubezpieczeniowa”, 26 VIII 2003).

Przytoczone w przykładach (2)-(3) przysłowia (zasady) spełniają takie kryteria tekstowości, jak podmiotowość, nacechowanie gatunkowe i stylowe (potoczność), są wyraziste strukturalnie i znaczeniowo, stąd można je grupować w ciągi o sensie tożsamym bądź przeciwstawnym, jak w (2).

Kwalifikator gatunkowy może też wystąpić w połączeniu z kwalifikatorem stylowym ${ }^{6}$ :

(4) Tam ci dopiero ludziska, zwani przez pospólstwo wyborcze eurodeputowanymi, puszczają wodze swojego gadania. Mało tego, to ich gadanie zostanie

6 Zdaniem jednego z Recenzentów artykułu zdanie To nie sztuka zabić kruka, ale sowę trafić w głowę nie jest przysłowiem, lecz (zgodnie z internetową kwerendą) „uskrzydlonym fragmentem żartobliwego czterowiersza”, przypisywanego Józefowi Piłsudskiemu: „To nie sztuka zabić kruka / ani sowę trafić w głowę, / ale sztuka całkiem świeża / trafić z Bezdan do Nieświeża”. Nadawca cytowany w przykładzie (4) zdanie to nazywa przysłowiem ludowym, na czym poprzestaję, zgodnie z postulatem tekstologii integralnej, aby odwoływać się do „naturalnej potocznej praktyki językowej i potocznej wiedzy o tekstach” (Bartmiński, Niebrzegowska-Bartmińska 2009: 12). Fraza ta notowana jest zresztą w Nowej księdze przysłów i wyrażeń przysłowiowych polskich pod red. Juliana Krzyżanowskiego pod hasłem sztuka 12 w następujących wariantach: Nie sztuka zabić kruka, ale wronie wylizać podogonie (1886), Nie sztuka zabić kruka, ale go złapać (1894), To nie sztuka zabić kruka, ale sowe trafić w głowę $(1894,1957)$, To nie sztuka mierząc w kruka stara sowe trafić w głowę, ale sztuka całkiem świeża goła pięścia zabić jeża (1897), To nie sztuka zabić kruka ani sowę trafić w głowę, ale sztuka to jest świeża goła dupa siąść na jeża (1956), To nie sztuka zabić kruka, ale sztuka całkiem świeża gołóm dupóm zabić jeża (1956). 
przetłumaczone na wiele języków. To ci dopiero będzie gratka nie lada jaka, bo - jak mówi przysłowie ludowe - „to nie sztuka zabić kruka, ale sowę trafić w głowę", dlatego chłopcy, sprawdzeni w wielu bojach wyborczych, ruszyli na wyprzódki, kto pierwszy, ten lepszy (Stefan, Gadanie a robienie, „Gazeta Radomszczańska”, 24 VI 2009).

Autor wypowiedzi (5) uwidacznia zwłaszcza dydaktyczną intencję przysłów:

(5) Gdybanie jest obecne w naszym życiu już od zarania, czyli od wczesnego dzieciństwa, później zaczęły się gdybania o trochę innym zabarwieniu emocjonalnym. Gdyby babcia miała wąsy, toby był dziadek, gdyby kózka nie skakała, toby nóżki nie złamała, do absurdu doprowadzone jest „gdyby” w wierszu Juliana Tuwima Gdyby, który kończy się jednym wielkim: ,jaki by wtedy, jaki by wtedy był plusk” (Stefan, Gdyby, „Gazeta Radomszczańska”, 21 X 2010).

Paremie mają pouczać o standardowych zachowaniach, oczekiwanych przez wspólnotę komunikacyjno-kulturową. W przykładzie (5) jest to pouczenie, że ponosi się konsekwencje swoich działań: Gdyby kózka nie skakała, toby nóżki nie złamała. Fraza Gdyby babcia miała wasy, toby była dziadkiem, używana także z intencją przygany, z potencjalnym dopowiedzeniem: nie filozofuj, poświadcza przynależność paremii do stylu potocznego, unikającego nadmiernej spekulatywności, a przede wszystkim jest przykładem gry językowej, ironicznego żartu (z „gdybania”) i swego rodzaju sarkastycznym przedrzeźnianiem.

(6) Im kryteria jej oceny i cel są bardziej jasne, tym mniejsza rola związków zawodowych i gorliwych posłów. Im bagno bzdur głębsze, tym obroty wskazówek zegara w pracy wolniejsze i czas najwyższy na zmiany. Bo w pracy jak Kuba Bogu, tak Bóg Kubie i żadna norma tego nie zmieni (Alicja Peplińska, Wszystkie soboty wolne, „Dziennik Bałtycki”, 3 VIII 1999).

Przykłady (3) i (6) pokazują, że przysłowia dają się wkomponować w kontekst i sytuację, tzn. ich ogólny sens (w przypadku Jak Kuba Bogu, tak Bóg Kubie można go objaśnić jako 'ludzie za postępowanie z nimi w dany sposób odpłacają tym samym') zostaje ukonkretniony przez odwołanie do tego, o czym aktualnie mowa; w przykładach (1), (3) i (6) przysłowie Jak Kuba Bogu, tak Bóg Kubie odnoszone jest kolejno przez mówiących do polityki, pracy i etyki.

W cytatach (7) i (8) pojawia się rozpoznawalna jako jednostka językowa (w przyjmowanym przeze mnie rozumieniu), mająca sens metaforyczny fraza Przyjdzie koza do woza: 
(7) Pewnie wkrótce poleci i ta, której serwery wykorzystuje dla swoich niecnych działań minister. A wtedy przyjdzie koza do woza. Chyba że woza nie stanie (Aleksander Malak, Cuius regio eius religio, „Gazeta Wrocławska”, 13 IX 2002).

(8) Wiktor zmiął papier ze złości i rzucił pod ławkę. Ale potem podniósł, wyprostował i schował papier do kieszeni. Jeszcze przyjdzie koza do woza, wtedy im to pokaże. Jednocześnie zauważył, że podłogą sunie papierowa kula. To list od Rudnioka. W ten sposób porozumiewali się, odkąd kierownik za ciągłe rozmowy na lekcjach rozsadził ich do różnych ławek (Edmund Niziurski, Księga urwisów, Wrocław 1954).

W przykładach (2), (5), (7) i (8) powtarzają się takie same literalnie ciągi słów odpowiednio: gdyby kózka nie skakała, toby nóżki nie złamała oraz przyjdzie koza do woza - formalnie będące zdaniami, które równocześnie stanowią wydzielające się z kontekstu całostki, komunikujące pewne prawdy ogólne i dzięki temu rozpoznawalne jako przysłowia. Ich integralność jest na płaszczyźnie formalnej dodatkowo zabezpieczana przez rym (koza - woza), który jest tu wyrazistym sygnałem jedności strukturalnej. To samo dotyczy pozostałych przykładów (skakała - złamała; zagrodzie - wojewodzie; wojewodzie - smrodzie; sztuka - kruka, sowę - głowę). Składniowym środkiem integracji są także paralelizmy (Kuba - Bóg) i kontrasty (szlachcic wojewoda; babcia - dziadek).

(9) Jak mówi stare przysłowie: w internecie żaden pies nie jest samotny. Szybko trafiłem na osoby w podobnej sytuacji, a grupa na Facebooku stała się moją szkołą życia. Ciekawe, że historie wychodzenia z nałogu zaczynały się najczęściej od jakiejś katastrofy. Odniosłem wrażenie, że mało kto pozbywa się telewizora dobrowolnie (Marcin Wicha, Przerwa w życiorysie, „Tygodnik Powszechny" 13 II 2011).

Wprowadzone za pomocą sygnału przytoczenia jest w przykładzie (9) quasi-paremiczne wyrażenie $w$ internecie żaden pies nie jest samotny. Cały tekst jest żartobliwy, a żart oparty jest na kontraście: stare przysłowie nie może dotyczyć współczesnych relacji między ludźmi komunikującymi się za pomocą sieci komputerowej. Natomiast sama ta quasi-paremia skonstruowana jest w sposób udany, tak że przypomina rzeczywiście istniejące przysłowia - jest ogólna (kwantyfikator żaden), przez co imituje przynależność do potocznej, powszechnej wiedzy o świecie, która zawiera sądy obiegowe, a dzięki temu niekwestionowalne, a także wyzyskuje stereotypowe wyobrażenie psa, który nie lubi samotności i szuka stada.

Już ten krótki przegląd wybranych przykładów pokazuje wyraźnie, że przysłowie spełnia wszystkie wcześniej zestawione warunki tekstowości. Przede wszystkim jest jednoznacznie wyodrębniane, otrzymuje wyraźną kwalifikację gatunkową (ma nazwę genologiczną: przysłowie). Ma swojego nadawcę (spełnia kryterium podmio- 
towości) i odbiorcę (zaadresowanie). Ma wyraźną intencję komunikacyjną: przywołanie paremii ma pouczać (2), uwiarygodniać słowa mówiącego lub jego postępowanie (1), a także informować o stosunkach panujących w świecie (2)-(6) ${ }^{7}$. Paremie należą do stylu potocznego (2)-(4), są jednym z gatunków dydaktycznych (2). Są wyraziste pod względem struktury (integralność), czego dowodzi między innymi włączanie ich do dłuższych wypowiedzi jako tekstów w tekście, a także powtarzalne cechy, jak obecność rymów, paralelizmów i kontrastów (branych często za cechy definicyjne paremii, por. Głowiński 2000). Są spójne linearnie i semantycznie ${ }^{8}$. Mają cechę informatywności, orzekają coś o czymś. Ich sens aktualizuje się w konkretnych sytuacjach komunikacyjnych (sytuacyjność), por. wspomniane przykłady (1), (3) i (6). Dają się zestawiać w ciągi pozostających w dialogu wypowiedzi, zgodnych lub niezgodnych w ocenie danego wycinka rzeczywistości (2). Mogą otwierać tekst, spajać go wewnętrznie i zamykać (Trzynadlowski 1977: 22). Wykazują podatność na przetwarzanie - możliwe są ich rozmaite parafrazy, przeróbki i trawestacje, jak na przykład w (9).

\section{3. „Tekst minimalny" - „tekst prototypowy"}

Kryterium bycia tekstem nie jest liczba słów czy zdań, z których składa się dana wypowiedź. Przyjmuję za autorami Tekstologii, że w pełni komunikatywnym tekstem (wypowiedzią) może być pojedynczy wyraz, grupa wyrazów, równoważnik zdania, zdanie. Co o tym decyduje? Autorzy wskazują na kompletność pod względem komunikacyjnym, powołując się na stanowisko Bachtina, że

[k]ażda replika, nawet najkrótsza, nagle urwana, wyrażając pewną postawę mówiącego, wobec której można zająć jakieś stanowisko, odpowiedzieć na nią, jest w szczególny sposób zwieńczona (Bachtin 1986: 364),

i rekapitulują omawianą tu kwestię w następujący sposób:

Zdanie (i każde wyrażenie jednowyrazowe) staje się tekstem, kiedy zostaje rozpoznana i przypisana mu intencja, z jaką zostało przez kogoś powiedziane [...], kiedy poddaje się interpretacji w kategoriach gatunku mowy. Dopiero zdanie tak zakwalifikowane przez odbiorcę staje się komunikatem, wypowiedzią. To samo dotyczy wykrzyknień i zawiadomień [...] (Bartmiński, Niebrzegowska-Bartmińska 2009: 48).

7 Na podstawie przytoczonych fragmentów można wnioskować, że cytowanie przysłów jest zabiegiem obiektywizującym subiektywne sądy mówiących przez odwołanie do opinio communis.

8 Niektórzy badacze (np. Bralewski 2005: 12-13, 17, 19) mają co do tego wątpliwości, uznając napięcie między dosłownym a naddanym sensem paremii za powodujące ich niezrozumiałość i niekomunikatywność. 
Autorzy Tekstologii wprowadzają dalej pojęcie „tekstu minimalnego” (ibid.: 44) ${ }^{9}$ i „tekstu prototypowego” (ibid.: 48), ale nie ustalają jednoznacznie relacji między nimi. Dla określenia statusu przysłów jest to rozróżnienie ważne.

Określenie przysłów mianem „tekstu minimalnego" przewija się w wypowiedziach zarówno językoznawców, jak teoretyków literatury i folklorystów, zwłaszcza w kontekście przeciwstawienia przysłów związkom frazeologicznym, por. np.:

Frazeologizmy [...] nie są tekstami. To różni frazeologizmy od przysłów (niekiedy zwanych przysłowiami właściwymi), które są minimalnymi tekstami utrwalonymi w społecznym zasobie tekstów i formuł tekstowych (Lewicki, Pajdzińska 2001: 315).

Dla potrzeb językoznawstwa przysłowia trzeba definiować jako minimalne teksty, które do wypowiedzi wchodzą jako cytaty - „tekst w tekście” (Lewicki 2009: 15).

Danuta Buttler nazwała przysłowie „minitekstem” (Buttler 1989: 332), Krzysztof Wrocławski pisał, że „za formę folkloru dopuszczającą tekst »minimalny«, jednozdaniowy uważane jest przysłowie" (Wrocławski 1998: 192). J. Krzyżanowski określał przysłowie „najmniejszym utworem literackim” (np. Krzyżanowski 2003); podobnego sformułowania używali Grigorij Piermiakow („miniatury artystyczne”; Piermiakow 1972: 36), Karlheinz Stierle („minimalny tekst systematyczny”; Stierle 1978: 340; por. Ługowska 1993: 109-110), Gérard Genette („tekst literacki minimalnych rozmiarów"; Genette 2014: 13) ${ }^{10}$.

Przytoczone opinie są raczej intuicyjne niż terminologiczne. Wypada dodać, że przysłowia są tekstami minimalnymi o specyficznym statusie wyznaczonym przez ich powtarzalność. Należą do tak zwanych klisz językowych w rozumieniu Piermiakowa (1972). A powtarzalność pociąga za sobą ich rozpoznawalność jako określonych „całostek” w potoku mowy. Należy więc odpowiedzieć na pytanie, jak te opinie pogodzić ze stanowiskiem autorów Tekstologii, że tekstem mogą być już pojedyncze słowa i wyrażenia użyte na przykład w funkcji wykrzyknień i zawiadomień - Olaboga!, Halo!, Kolego!, Dzień dobry, Godziny urzędowania (por. Bartmiński, Niebrzegowska-Bartmińska 2009: 40-43).

Proponuję rozdzielić pojęcia "tekstu prototypowego" i „tekstu minimalnego" oraz konfigurować je na cztery różne sposoby. Relacje między nimi można wtedy ująć w postaci diagramu, którego oś pozioma $(x)$ rozciąga się od [-MINIMALNy] do [+MINIMALNY], pionowa $(y)$ - od [-PROTOTYPOWY] do [+PROTOTYPOWY]:

9 Pojęcie „tekstu minimalnego" jest pomyślane na wzór znanej ze składni koncepcji zdania minimalnego, które zawiera wyłącznie elementy obligatoryjne (Karolak 1984: 13). Można je wyrazić schematycznie: tekst minimalny $=($ temat + remat $)+$ nacechowanie gatunkowe.

10 André Jolles użył w tytule swojej książki Einfache Formen (1929) określenia formy proste, jednakże objął nimi różne gatunki (Legende, Sage, Mythe, Rätsel, Spruch, Kasus, Memorabile, Märchen, Witz). Przysłowie oraz jego odmiany (np. welleryzm) pojawiają się natomiast w encyklopedii Simple Forms pod redakcją Waltera A. Kocha (1990). 


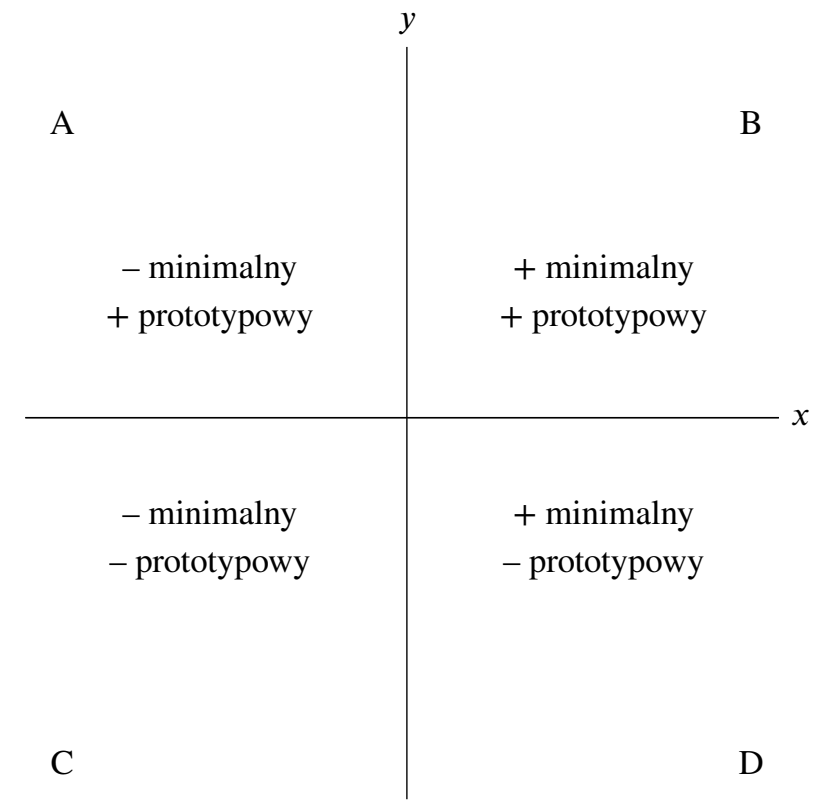

Tekstem minimalnym (ćwiartka $D$ ) są wykrzyknienia i zawiadomienia, np. Och!, Ach!, Artykuly sportowe. Minimalnym prototypowym tekstem (ćwiartka $B$ ) jest przysłowie. Tekstem prototypowym (ćwiartka $A$ ) - np. bajka o Czerwonym Kapturku. Nieminimalna i nieprototypowa (ćwiartka $C$ ) jest np. powieść, powiedzmy: Lalka Bolesława Prusa.

\section{Podsumowanie}

Jaki jest więc tekstologiczny status przysłowia? Jest ono prototypowym tekstem minimalnym, różnym zarówno od wykrzyknień i zawiadomień typu Halo!, Godziny urzędowania jako tekstów minimalnych nieprototypowych, jak i od nieminimalnych i nieprototypowych tekstów długich, np. powieści, a także od tekstów prototypowych, jak bajki, które z zasady są dłuższe (nieminimalne).

\section{Literatura}

BACHTin M., 1986, Estetyka twórczości słownej, tłum. D. Ulicka, oprac. i wstęp E. Czaplejewicz, Warszawa.

BARTMiński J., 1998, Tekst jako przedmiot tekstologii lingwistycznej, [w:] J. Bartmiński, B. Boniecka (red.), Tekst. Problemy teoretyczne, Lublin, s. 9-25. 
BARTMIŃski J., 2004, Założenia programu nauki o współczesnym języku polskim, [w:] idem (red.), Współczesna polszczyzna. Wybór opracowań, t. 1: Programy dydaktyczne, bibliografia, etykieta językowa, Lublin, s. 9-16.

Bartmiński J., Niebrzegowska-Bartmińska S., 2009, Tekstologia, Warszawa.

De BeAugrande R.-A., Dressler W.U., 1990, Wstęp do lingwistyki tekstu, tłum. A. Szwedek, Warszawa.

BogusŁawski A., 1976, O zasadach rejestracji jednostek języka, „Poradnik Językowy” nr 8, S. $356-364$.

BogusŁawski A., 1983, Słowo o zdaniu i o tekście, [w:] T. Dobrzyńska, E. Janus (red.), Tekst i zdanie. Zbiór studiów, Wrocław, s. 7-31.

BonieckA B., 1999, Lingwistyka tekstu. Teoria i praktyka, Lublin.

Bralewski D., 2005, Czy przysłowie jest jednostka języka?, [w:] A.M. Lewicki (red.), Problemy frazeologii europejskiej, t. 7, Lublin, s. 9-24.

Buttler D., 1989, Dlaczego zanikają przysłowia w dwudziestowiecznej polszczyźnie?, „Poradnik Językowy" nr 5, s. 332-337.

Chомккy N., 1957, Syntactic Structures, The Hague.

Dobrzyńska T., 1991, Tekst. Próba syntezy, „Pamiętnik Literacki” z. 2, s. 142-183.

DuszaK A., 1998, Tekst, dyskurs, komunikacja międzykulturowa, Warszawa.

Furdal A., 1990, Językoznawstwo otwarte, Wrocław.

GARBAL Ł., 2011, Edytorstwo. Jak wydawać współczesne teksty literackie, Warszawa.

Genette G., 2014, Palimpsesty. Literatura drugiego stopnia, tłum. T. Stróżyński, A. Milecki, Gdańsk.

GŁowı́́ski M., 2000, Przysłowie, [w:] J. Sławiński (red.), Słownik terminów literackich, Wrocław, s. 451.

Golıński Z., 1969, Edytorstwo. Tekstologia. Przekroje, Wrocław.

Górski K., 2011, Tekstologia i edytorstwo dzieł literackich, Toruń.

GrzegorCzy KowA R., 1999, Wykłady z polskiej składni, Warszawa.

von Humboldt W., 1836/2001, Rozmaitość języków a rozwój umysłowy ludzkości, tłum. i wprow. E.M. Kowalska, Lublin.

Jolles A., 1929, Einfache Formen. Legende, Sage, Mythe, Rätsel, Spruch, Kasus, Memorabile, Märchen, Witz, „Konzepte der Sprach- und Literaturwissenschaft” t. 15, Halle.

KAROLAK S., 1984, Składnia wyrażeń predykatywnych, [w:] S. Urbańczyk (red. nauk.), Gramatyka współczesnego języka polskiego, t. 1, Z. Topolińska (red.), Składnia, Warszawa, s. $11-211$.

Kосн W.A. (red.), 1990, Simple Forms. An Encyclopedia of Simple Text Types in Lore and Literature, Bochum.

Krzyżanowski J. (red.), 1969-1978, Nowa księga przysłów i wyrażeń przysłowiowych polskich, w oparciu o dzieło Samuela Adalberga oprac. zesp. red. pod kier. J. Krzyżanowskiego, t. I-IV, Warszawa.

Krzyżanowski J., 2003, Przysłowie, [w:] A. Hutnikiewicz, A. Lam (red.), Literatura polska XX wieku. Przewodnik encyklopedyczny, t. 2, Warszawa, s. 85.

LEwICKI A.M., 2009, Uwagi wstępne ofrazach, [w:] idem, Studia z polskiej frazeologii, „Kompendium frazeologa", t. 4, Łask, s. 15-29.

Lewicki A.M., Pajdzińska A., 2001, Frazeologia, [w:] J. Bartmiński (red.), Współczesny język polski, Lublin, s. 315-333.

Loth R., 2006, Podstawowe pojęcia i problemy tekstologii i edytorstwa naukowego, Warszawa. 
Ługowska J., 1993, W świecie ludowych opowiadań. Teksty, gatunki, intencje narracyjne, Wrocław.

Mayenowa M.R., 1974, Poetyka teoretyczna. Zagadnienia języka, Wrocław.

NiebrZEgOWSKA-BARTMIŃsKa S., 2007, Wzorce tekstów ustnych w perspektywie etnolingwistycznej, Lublin.

NiebrZegowsKa-BARTMiŃsKa S., 2015, Tekstocentryzm a kwestie podmiotowości w edukacji polonistycznej, wystąpienie na Kongresie Dydaktycznym w Katowicach (mszps).

Piermiakow G., 1972, Przysłowia i zwroty przysłowiowe, tłum. H. Walińska, „Literatura Ludowa" nr 1, s. 35-48.

DE SAUSsure F., 1916/2002, Kurs językoznawstwa ogólnego, tłum. K. Kasprzyk, Warszawa.

StIERle K., 1978, Historia jako exemplum - exemplum jako historia. O pragmatyce i poetyce tekstów narracyjnych, tłum. M. Łukasiewicz, „Pamiętnik Literacki” z. 4, s. 333-363.

TrZYNADlowski J., 1976, Edytorstwo. Tekst, język, opracowanie, Warszawa.

TrzynADLOWSKi J., 1977, Małe formy literackie, Wrocław.

Wasiuta S., w przygotowaniu, Przysłowie jako tekst minimalny, Uniwersytet Marii Curie-Skłodowskiej, Instytut Filologii Polskiej, rozprawa doktorska, mszps.

Witosz B., 1998, Tekst jako wspólny przedmiot badań teorii tekstu, stylistyki i poetyki, „Stylistyka" VII, s. 45-6o.

WrocŁawski K., 1998, O niektórych postaciach tekstów folkloru i ich dokumentowaniu, [w:] J. Bartmiński, B. Boniecka (red.), Tekst. Problemy teoretyczne, Lublin, s. 187-195.

Żydek-Bednarczuk U., 2005, Wprowadzenie do lingwistycznej analizy tekstu, Kraków.

\section{Proverb as a linguistic unit (from the perspective of integral text linguistics) Summary}

The paper presents arguments in favour of treating proverbs as text, and in consequence, as linguistic units. The starting point is the concept of integral text linguistics formulated by Jerzy Bartmiński and Stanisława Niebrzegowska-Bartmińska in their handbook Tekstologia ('Text linguistics', 2009). According to this theory, text is a supra-sentence linguistic unit, and the text of the parole plane corresponds to an abstract template of the langue plane. The argumentation that this paper presents in favour of regarding proverbs as text is based on an analysis of examples from the National Corpus of Polish which contain proverbs. It shows clearly that proverbs fulfill all of the requirements of textuality; among others, they are uniquely distinguished as a communicative whole, they receive a clear genre qualification, they have their senders and receivers, a clear communicative intent and a stylistic qualifier. The final part of the paper contains a proposition to describe proverbs as "minimal text", and to separate the terms minimal text and prototypical text. Within this interpretation, a proverb is a prototypical minimal text that is different from both non-prototypical minimal texts, and from non-prototypical non-minimal long texts such as novels, as well as prototypical texts such as fables which tend to be longer (non-minimal). 